\title{
Sonidegib, a Novel Inhibitor of Suicidal Erythrocyte Death
}

\author{
Abdulla Al Mamun Bhuyan ${ }^{\mathrm{a}}$ Itishri Sahu ${ }^{\mathrm{a}}$ Hang Cao Florian Lang $^{\mathrm{b}, \mathrm{c}}$ \\ aDepartments of Cardiology, Cardiovascular Medicine and ' $V$ egetative and Clinical Physiology, \\ Eberhard-Karls-University Tuebingen, 'Department of Molecular Medicine II, Medical Faculty, Heinrich \\ Heine University, Düsseldorf, Germany
}

\section{Key Words}

Phosphatidylserine - Eryptosis - Energy depletion - Oxidative stress - Hyperosmotic shock • Ionomycin • Calcium

\begin{abstract}
Background/Aims: The Hedgehog pathway disrupting drug sonidegib is used in the treatment of basal cell carcinoma. Side effects of sonidegib include anemia, which could result either from impaired erythropoiesis or from loss of erythrocytes e.g. due to suicidal erythrocyte death or eryptosis, which is characterized by cell membrane scrambling with phosphatidylserine translocation to the cell surface and by cell shrinkage. Eryptosis is stimulated by cell stress, including energy depletion, hyperosmotic shock, oxidative stress and excessive increase of cytosolic $\mathrm{Ca}^{2+}$ activity $\left(\left[\mathrm{Ca}^{2+}\right]_{\mathrm{i}}\right)$. The present study explored, whether sonidegib exerts an effect on eryptosis. Methods: Human erythrocytes have been treated with energy depletion (glucose withdrawal for 48 hours), hyperosmotic shock (addition of $550 \mathrm{mM}$ sucrose for 6 hours), oxidative stress (addition of $0.3 \mathrm{mM}$ tert-butylhydroperoxide [tBOOH] for $50 \mathrm{~min}$ ) or $\mathrm{Ca}^{2+}$ ionophore ionomycin (1 $\mu \mathrm{M}$ for $\left.60 \mathrm{~min}\right)$ in absence and presence of sonidegib (2-6 $\mu \mathrm{g} /$ $\mathrm{ml}$ ). After treatment flow cytometry was employed to quantify phosphatidylserine exposure at the cell surface from annexin-V-binding, and cell volume from forward scatter. Hemolysis was estimated from the hemoglobin concentration in the supernatant. Results: In the absence of cell stress exposure to sonidegib did not significantly modify annexin-V-binding or forward scatter, but triggered hemolysis. Energy depletion, hyperosmotic shock, oxidative stress and ionomycin, all markedly and significantly increased the percentage of annexin-V-binding erythrocytes, and decreased the forward scatter. Sonidegib significantly blunted the effect of energy depletion, hyperosmotic shock, and oxidative stress, but not of ionomycin on annexin-V-binding. Sonidegib further significantly blunted the effect of energy depletion, but not of hyperosmotic shock, oxidative stress, and ionomycin on forward scatter. Conclusions: Sonidegib is a novel inhibitor of erythrocyte cell membrane scrambling following energy depletion, hyperosmotic shock and oxidative stress.




\section{Introduction}

The smoothened (SMO) inhibitor sonidegib interferes with the Hedgehog pathway [1] and is used in the treatment of basal cell carcinoma [1-11]. Side effects of the drug include anemia [1], which, at least in theory, could result from stimulation of eryptosis, the suicidal erythrocyte death [12-16]. A hallmark of eryptosis is cell membrane scrambling with phosphatidylserine translocation to the cell surface, which is characterized by cell membrane scrambling with phosphatidylserine translocation to the cell surface [12]. A second hallmark of eryptosis is cell shrinkage due to activation of ion channels in the cell membrane [17]. Stimulators of eryptosis include energy depletion [12], hyperosmotic shock [12], and oxidative stress [12]. Signaling participating in the orchestration of eryptosis include increase of cytosolic $\mathrm{Ca}^{2+}$ activity $\left(\left[\mathrm{Ca}^{2+}\right]_{\mathrm{i}}\right)[12]$, ceramide [18], caspases [12, 19, 20], G-protein Goi2 [21], CDK4 [22] casein kinase $1 \alpha$ [12], Janus-activated kinase JAK3 [12], protein kinase C [12], and p38 kinase [12]. Signaling mechanisms inhibiting eryptosis include the kinases AMPK [12], cGMP-dependent protein kinase [12], MSK1/2 [23], PAK2 [12] and sorafenib/sunitinib sensitive kinases [12]. Eryptosis is stimulated by a wide variety of xenobiotics [12, 23-77] and enhanced eryptosis is observed in several clinical conditions including iron deficiency [12], dehydration [78], hyperphosphatemia [68], vitamin D excess [32], chronic kidney disease (CKD) [79-83] hemolytic-uremic syndrome [84], diabetes [85], hepatic failure [86, 87], malignancy [88, 89], autoimmune hemolytic anemia [90], lack of sialic acid [91], arteriitis [92], sepsis [93], sickle-cell disease [12], beta-thalassemia [12], $\mathrm{Hb}-\mathrm{C}$ and G6PD-deficiency [12], Wilsons disease [94], as well as advanced age [95]. Eryptosis further increases following storage for transfusion [96-98].

The present study explored, whether sonidegib influences eryptosis. Thus, human erythrocytes have been exposed to sonidegib without or with additional exposure to energy depletion, hyperosmotic shock, oxidative stress, as well as $\mathrm{Ca}^{2+}$ loading. In order to identify eryptotic erythrocytes, phosphatidylserine surface abundance and cell volume were determined by flow cytometry.

\section{Materials and Methods}

Erythrocytes, solutions and chemicals

Fresh Li-Heparin-anticoagulated blood samples were kindly provided by the blood bank of the University of Tübingen. The study is approved by the ethics committee of the University of Tübingen (184/2003 V). The blood was centrifuged at $120 \mathrm{~g}$ for $20 \mathrm{~min}$ at $21^{\circ} \mathrm{C}$ and the platelets and leukocytes-containing supernatant was disposed. Erythrocytes were incubated in vitro at a hematocrit of $0.4 \%$ in Ringer solution containing (in $\mathrm{mM}$ ) $125 \mathrm{NaCl}, 5 \mathrm{KCl}, 1 \mathrm{MgSO}_{4}, 32 \mathrm{~N}$-2-hydroxyethylpiperazine-N-2-ethanesulfonic acid (HEPES; pH 7.4), 5 glucose, 1 $\mathrm{CaCl}_{2}$, at $37^{\circ} \mathrm{C}$ for 48 hours. Where indicated, erythrocytes were exposed for 48 hours to glucose depleted Ringer solution, for 6 hours to hypertonic Ringer (addition of 550 mM sucrose, Sigma Aldrich, Hamburg, Germany), for 50 minutes to the oxidant tert-butyl-hydroperoxide (0.3 mM, Sigma Aldrich, Hamburg, Germany), or for 60 minutes to $\mathrm{Ca}^{2+}$ ionophore ionomycin ( $1 \mu \mathrm{M}$, Merck Millipore, Darmstadt, Germany), each in the absence and presence of sonidegib (MedChem Express, Princeton, USA).

\section{Annexin-V-binding and forward scatter}

After incubation under the respective experimental condition, a $150 \mu \mathrm{l}$ cell suspension was washed in Ringer solution containing $5 \mathrm{mM} \mathrm{CaCl}_{2}$ and then stained with Annexin-V-FITC (1:200 dilution; ImmunoTools, Friesoythe, Germany) in this solution at $37^{\circ} \mathrm{C}$ for $15 \mathrm{~min}$ under protection from light. The annexin- $\mathrm{V}$ abundance at the erythrocyte surface was subsequently determined on a FACS Calibur (BD, Heidelberg, Germany). Annexin-V-binding was measured with an excitation wavelength of $488 \mathrm{~nm}$ and an emission wavelength of $530 \mathrm{~nm}$. A marker (M1) was placed to set an arbitrary threshold between annexin-V-binding cells and control cells. The same threshold was used for untreated and sonidegib treated erythrocytes. A dot 
plot of forward scatter (FSC) vs. side scatter (SSC) was set to linear scale for both parameters. The threshold of forward scatter was set at the default value of " 52 ".

\section{Intracellular $\mathrm{Ca}^{2+}$}

After incubation, erythrocytes were washed in Ringer solution and loaded with Fluo-3/AM (Biotium, Hayward, USA) in Ringer solution containing $5 \mathrm{mM} \mathrm{CaCl}_{2}$ and $5 \mu \mathrm{M}$ Fluo-3/AM. The cells were incubated at $37^{\circ} \mathrm{C}$ for $30 \mathrm{~min} . \mathrm{Ca}^{2+}$-dependent fluorescence intensity was measured with an excitation wavelength of 488 $\mathrm{nm}$ and an emission wavelength of $530 \mathrm{~nm}$ on a FACS Calibur.

\section{Hemolysis}

Following incubation, the erythrocyte suspension was centrifuged for $3 \mathrm{~min}$ at $1600 \mathrm{rpm}, 4^{\circ} \mathrm{C}$, and the supernatant harvested. As a measure of hemolysis, the hemoglobin ( $\mathrm{Hb})$ concentration in the supernatant was determined photometrically at $405 \mathrm{~nm}$. The absorption of the supernatant of erythrocytes lysed in distilled water was defined as $100 \%$ hemolysis.

\section{Statistics}

Data are expressed as arithmetic means \pm SEM. As indicated in the figure legends, statistical analysis was made using ANOVA with Tukey's test as post-test. $\mathrm{n}$ denotes the number of different erythrocyte specimens studied. Since different erythrocyte specimens used in distinct experiments are differently susceptible to triggers of eryptosis, the same erythrocyte specimens have been used for control and experimental conditions.

\section{Results}

The present study addressed a putative influence of sonidegib on eryptosis, the suicidal erythrocyte death. Thus, the key features of eryptosis, i.e. cell membrane scrambling and cell shrinkage were quantified by flow cytometry. Phosphatidylserine exposing erythrocytes were identified utilizing annexin-V-binding to phosphatidylserine, cell volume was estimated utilizing forward scatter.

The percentage of human erythrocytes binding annexin-V after 48 hours incubation in standard, glucose containing, Ringer was low $(1.58 \pm 0.08 \%, \mathrm{n}=14)$ and not significantly

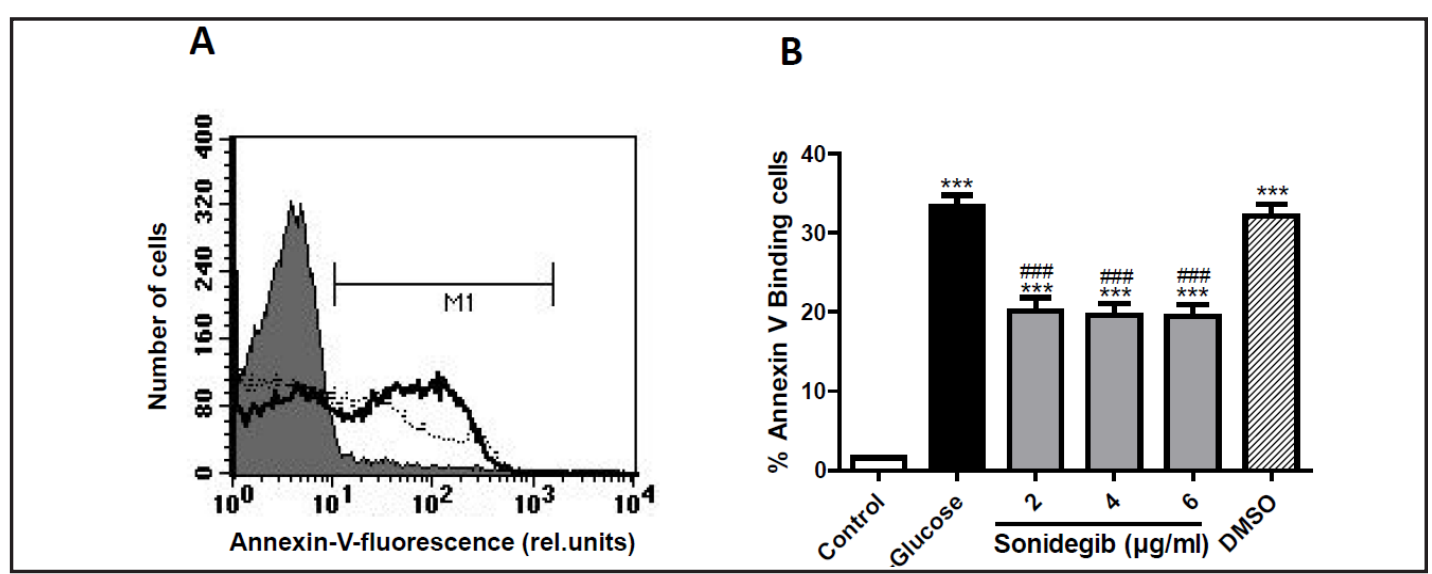

Fig. 1. Sonidegib sensitivity of phosphatidylserine exposure following energy depletion. A. Original histograms of annexin-V-binding of erythrocytes following exposure for 48 hours to glucose containing Ringer solution (grey area), Ringer solution without glucose (black solid line) and Ringer solution without glucose and presence of sonidegib $(6 \mu \mathrm{g} / \mathrm{ml})$ (black dashed line). B. Arithmetic means \pm SEM $(n=14)$ of the percentage annexin-V-binding erythrocytes after a 48 hours treatment with Ringer solution with glucose (white bar) or without glucose in the absence (black bar) and presence (grey bars) of sonidegib (2-6 $\mathrm{\mu g}$ / $\mathrm{ml})$. Striped bar is in absence of glucose and presence of DMSO. ${ }^{* * *}(\mathrm{p}<0.001)$ indicates significant difference from the presence of glucose, \#\#\#(p<0.001) indicates significant difference from the absence of sonidegib (ANOVA). 
A

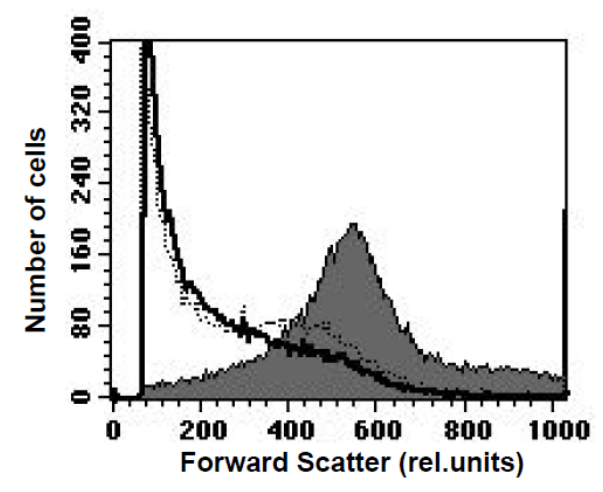

B

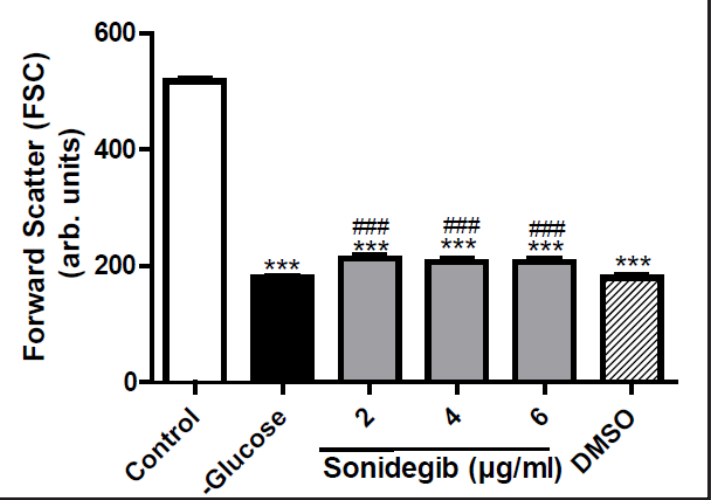

Fig. 2. Sonidegib sensitivity of erythrocyte shrinkage following energy depletion. A. Original histograms of forward scatter of erythrocytes following exposure for 48 hours to glucose containing Ringer solution (grey area), Ringer solution without glucose (black solid line) and Ringer solution without glucose and presence of sonidegib $(6 \mu \mathrm{g} / \mathrm{ml})$ (black dashed line). B. Arithmetic means \pm SEM $(n=14)$ of the erythrocyte forward scatter after a 48 hours treatment with Ringer solution with glucose (white bar) or without glucose in the absence (black bar) and presence (grey bars) of sonidegib (2-6 $\mathrm{g} / \mathrm{ml}$ ). Striped bar is in absence of glucose and presence of DMSO. ${ }^{* * *}(\mathrm{p}<0.001)$ indicates significant difference from the presence of glucose, $\# \# \#(p<0.001)$ indicates significant difference from the absence of sonidegib (ANOVA).

altered by addition of $6 \mu \mathrm{g} / \mathrm{ml}$ sonidegib $(3.45 \pm 0.50 \%, \mathrm{n}=14)$. The percentage of hemolytic erythrocytes after 48 hours incubation in standard, glucose containing, Ringer was similarly low $(3.11 \pm 0.36 \%, \mathrm{n}=5)$, but significantly increased by addition of $6 \mu \mathrm{g} / \mathrm{ml}$ sonidegib $(28.47$ $\pm 3.37 \%, \mathrm{n}=5$ ). Accordingly, in standard glucose containing Ringer solution, sonidegib did not appreciably influence erythrocyte cell membrane scrambling, but triggered hemolysis. As shown in Fig. 1, glucose removal was followed by a marked increase of the percentage of annexin-V-binding erythrocytes. At all sonidegib concentrations tested $(2-6 \mu \mathrm{g} / \mathrm{ml})$, the addition of the drug blunted the increase of the percentage annexin-V-binding erythrocytes following glucose deprivation. However, even in the presence of sonidegib, energy depletion significantly increased the percentage of phosphatidylserine exposing erythrocytes (Fig. 1). Accordingly, energy depletion triggered cell membrane scrambling, an effect partially, but not completely blunted in the presence of sonidegib.

Erythrocyte forward scatter reflecting erythrocyte volume was, following a 48 hours exposure to Ringer solution in the presence of glucose, again similar in the absence (517.30 \pm 4.76 a.u., $\mathrm{n}=14)$ and presence $(498.50 \pm 7.14$ a.u., $\mathrm{n}=14)$ of sonidegib $(6 \mu \mathrm{g} / \mathrm{ml})$. Accordingly, in standard glucose containing Ringer solution, sonidegib did not appreciably modify erythrocyte volume. As illustrated in Fig. 2, glucose removal was followed by a marked decrease of erythrocyte forward scatter, an observation pointing to marked cell shrinkage. At each sonidegib concentration tested $(2-6 \mu \mathrm{g} / \mathrm{ml})$, the addition of the drug slightly, but significantly, blunted the decrease of forward scatter following glucose deprivation. However, even in the presence of sonidegib, energy depletion was followed by a significant decrase of forwards scatter (Fig. 2). Accordingly, energy depletion triggered cell shrinkage, an effect partially, but not completely blunted in the presence of sonidegib.

Fluo3 fluorescence was employed to test, whether sonidegib modifies the influence of energy depletion on cytosolic $\mathrm{Ca}^{2+}$ activity. As a result, a 48 hours glucose deprivation increased Fluo3 fluorescence from $20.91 \pm 0.57(\mathrm{n}=14)$ to similarly high values in the absence $(61.19 \pm 2.81, \mathrm{n}=14)$ and presence of $2(54.7 \pm 2.76, \mathrm{n}=14), 4(50.08 \pm 2.33, \mathrm{n}=$ $14)$, or $6(51.89 \pm 2.54, \mathrm{n}=14) \mu \mathrm{g} / \mathrm{ml}$ sonidegib. 
A

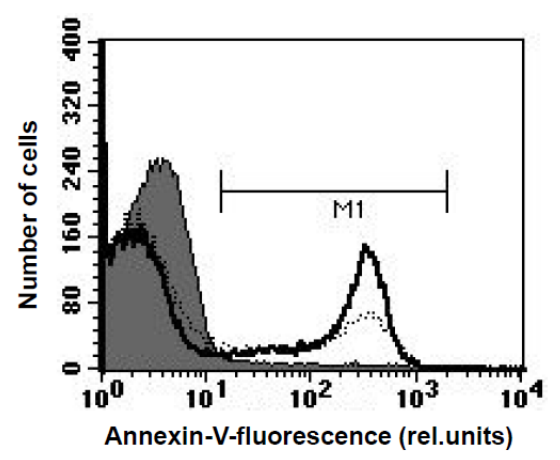

B

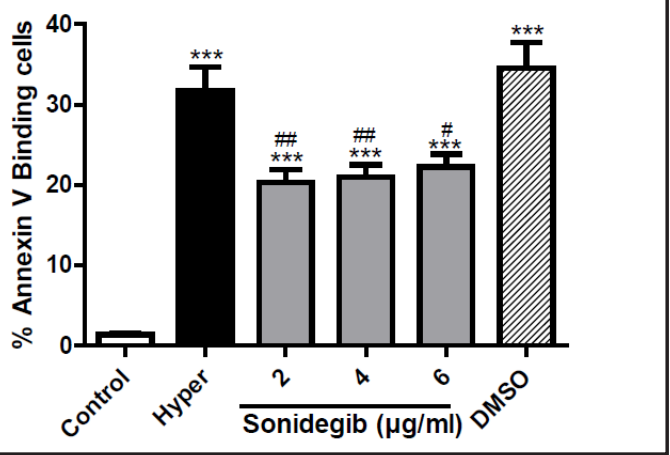

Fig. 3. Sonidegib sensitivity of phosphatidylserine exposure following hyperosmotic shock. A. Original histograms of annexin-V-binding of erythrocytes following exposure for 6 hours to isotonic Ringer solution (grey area), or hypertonic Ringer solution ( $550 \mathrm{mM}$ sucrose added) in absence (solid black line) or presence (black dashed line) of sonidegib $(6 \mu \mathrm{g} / \mathrm{ml})$. B. Arithmetic means \pm SEM $(\mathrm{n}=15)$ of the percentage annexinV-binding erythrocytes after a 6 hours treatment with isotonic Ringer solution (white bar), or hypertonic Ringer solution (550 mM sucrose added) in the absence (black bar) and presence (grey bars) of sonidegib $(2-6 \mu \mathrm{g} / \mathrm{ml})$. Striped bar is in presence of hypertonic solution and DMSO. ${ }^{* * *}(\mathrm{p}<0.001)$ indicates significant difference from isotonic Ringer, \# $(p<0.05)$, \#\#( $p<0.01)$ indicates significant difference from the absence of sonidegib (ANOVA).

A

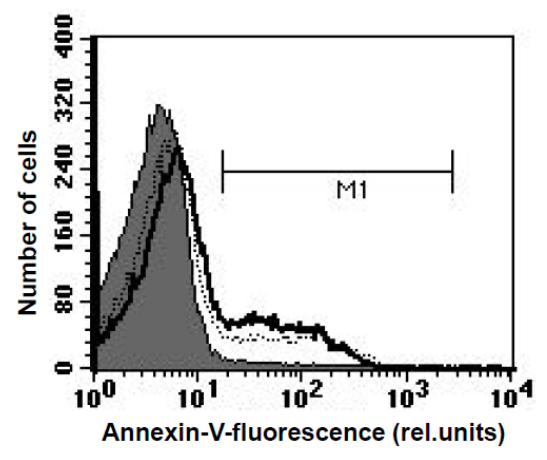

B

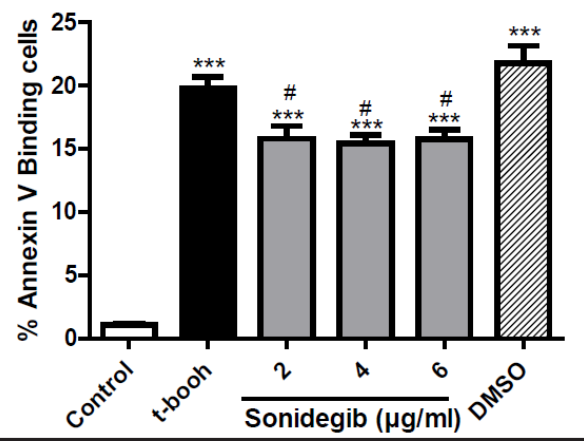

Fig. 4. Sonidegib sensitivity of phosphatidylserine exposure following oxidative stress. A. Original histograms of annexin-V-binding of erythrocytes following exposure for 50 min to Ringer solution without tert-butylhydroperoxide (grey area), or Ringer solution with tert-butylhydroperoxide (0.3 $\mathrm{mM}$ ) and absence (solid black line) or presence (black dashed line) of sonidegib $(6 \mu \mathrm{g} / \mathrm{ml})$. B. Arithmetic means $\pm \mathrm{SEM}(\mathrm{n}=$ 9) of the percentage annexin-V-binding erythrocytes after a 50 min treatment with Ringer solution without tert-butylhydroperoxide (white bar) or with tert-butylhydroperoxide $(0.3 \mathrm{mM})$ in the absence (black bar) and presence (grey bars) of sonidegib $(2-6 \mu \mathrm{g} / \mathrm{ml})$. Striped bar is in presence of tert-butylhydroperoxide and DMSO. ${ }^{* * *}(\mathrm{p}<0.001)$ indicates significant difference from the absence of tert-butylhydroperoxide, $\#(\mathrm{p}<0.05)$ indicates significant difference from the absence of sonidegib (ANOVA).

In order to explore the influence of sonidegib on the eryptosis following hyperosmotic shock the erythrocytes were exposed 6 hours to hypertonic Ringer (addition of $550 \mathrm{mM}$ sucrose). As shown in Fig. 3, hyperosmotic shock was followed by a marked increase of the percentage of annexin-V-binding erythrocytes. The addition of sonidegib blunted the increase of the percentage annexin-V-binding erythrocytes following hyperosmotic shock at all sonidegib concentrations tested $(2-6 \mu \mathrm{g} / \mathrm{ml})$. However, even in the presence of sonidegib, hyperosmotic shock significantly increased the percentage of phosphatidylserine exposing 
A

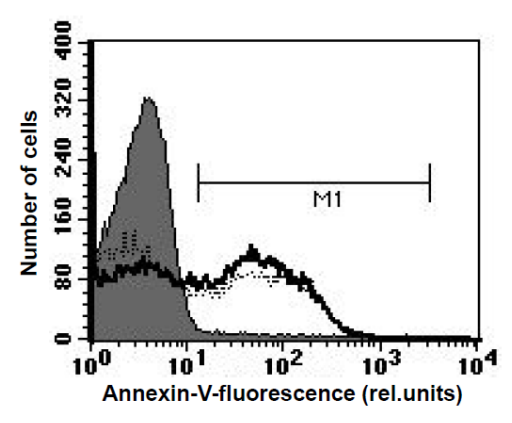

B

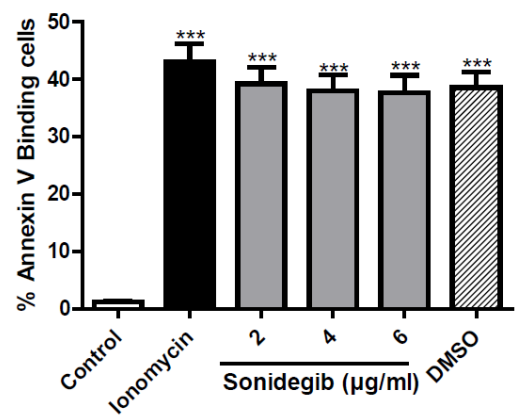

Fig. 5. Sonidegib sensitivity of phosphatidylserine exposure following $\mathrm{Ca}^{2+}$ loading. A. Original histograms of annexin-V-binding of erythrocytes following exposure for $60 \mathrm{~min}$ to Ringer solution without $\mathrm{Ca}^{2+}$ ionophore ionomycin (grey area), or Ringer solution with ionomycin $(1 \mu \mathrm{M})$ and absence (solid black line) or presence (black dashed line) of sonidegib $(6 \mu \mathrm{g} / \mathrm{ml})$. B. Arithmetic means \pm SEM $(\mathrm{n}=14)$ of the percentage annexin-Vbinding erythrocytes after a 60 min treatment with Ringer solution without ionomycin (white bar) or with ionomycin $(1 \mu \mathrm{M})$ in the absence (black bar) and presence (grey bars) of sonidegib $(2-6 \mu \mathrm{g} / \mathrm{ml})$. Striped bar is in presence of ionomycin and DMSO. ${ }^{* * *}(\mathrm{p}<0.001)$ indicates significant difference from the absence of ionomycin (ANOVA).

erythrocytes (Fig. 3). Accordingly, hyperosmotic shock triggered cell membrane scrambling, an effect partially, but not completely blunted in the presence of sonidegib.

Hyperosmotic shock was further followed by a marked decrease of forward scatter, reflecting erythrocyte shrinkage. The erythrocyte shrinkage following hyperosmotic shock was virtually identical in the absence $(378.5 \pm 10.58, \mathrm{n}=15)$ and presence of $2(394.2 \pm 10.3$, $\mathrm{n}=15), 4(389.9 \pm 9.69, \mathrm{n}=15)$, or $6(384 \pm 9, \mathrm{n}=15) \mu \mathrm{g} / \mathrm{ml}$ sonidegib. Accordingly, sonidegib did not significantly interfere with the effect of hyperosmotic shock on erythrocyte volume.

Further experiments addressed the influene of sonidegib on the eryptosis following oxidative stress. To this end, oxidative stress was induced by addition of $0.3 \mathrm{mM}$ tertbutylhydroperoxide (tBOOH) for 50 minutes. As illustrated in Fig. 4, oxidative stress was followed by a marked increase of the percentage of annexin-V-binding erythrocytes. The addition of sonidegib blunted the increase of the percentage annexin-V-binding erythrocytes following hyperosmotic shock at all sonidegib concentrations tested $(2-6 \mu \mathrm{g} / \mathrm{ml})$. However, even in the presence of sonidegib, oxidative stress significantly increased the percentage of phosphatidylserine exposing erythrocytes (Fig. 5). Accordingly, hyperosmotic shock triggered cell membrane scrambling, an effect partially, but not completely blunted in the presence of sonidegib.

Oxidative stress was further followed by a marked decrease of forward scatter, reflecting erythrocyte shrinkage. The erythrocyte shrinkage following oxidative stress was virtually identical in the absence (353.6 $\pm 5.09, \mathrm{n}=9)$ and presence of $2(355.3 \pm 3.62, \mathrm{n}=9), 4(357.5$ $\pm 6.40, \mathrm{n}=9)$, or $6(356.1 \pm 4.48, \mathrm{n}=9) \mu \mathrm{g} / \mathrm{ml}$ sonidegib. Accordingly, sonidegib did not significantly interfere with the effect of oxidative stress on erythrocyte volume.

A next series of experiments explored the influene of sonidegib on the eryptosis following $\mathrm{Ca}^{2+}$ entry, which was achieved by a $60 \mathrm{~min}$ exposure of erythrocytes to $\mathrm{Ca}^{2+}$ ionophore ionomycn $(1 \mu \mathrm{M})$. As illustrated in Fig. 5, exposure of the erythrocytes for 60 minutes to $1 \mu \mathrm{M}$ ionomycin was followed by a sharp increase of the percentage of annexin-Vbinding erythrocytes. The effect tended to be slightly blunted by sonidegib, an effect, however, not reaching statistical significance. Instead, even in the presence of sonidegib, ionomycin significantly increased the percentage of phosphatidylserine exposing erythrocytes (Fig. 5).

Exposure of the erythrocytes for 60 minutes to $1 \mu \mathrm{M}$ ionomycin was further followed by a sharp decrease of forward scatter to similarly low values in the absence (118.8 \pm 8.89 , $\mathrm{n}=14)$ and presence of $2(98.48 \pm 2.08, \mathrm{n}=14), 4(99.52 \pm 1.78, \mathrm{n}=14)$, or $6(99.33 \pm 1.55$, 
$\mathrm{n}=14) \mu \mathrm{g} / \mathrm{ml}$ sonidegib. The ionomycin induced cell shrinkage was thus not significantly modified by sonidegib.

\section{Discussion}

The present observations reveal a novel, completely unexpected effect of sonidegib on suicidal erythrocyte death. Treatment with sonidegib alone did not significantly modify the phosphatidylserine asymmetry of the cell membrane and cell volume. Instead, sonidegib significantly blunted the stimulating effect of energy depletion, hyperosmotic shock, and oxidative stress on cell membrane scrambling. The sonidegib concentrations required for this effect were in the range of concentrations $(778-6024 \mathrm{ng} / \mathrm{ml})$ encountered in the plasma of patients treated with sonidegib [99]. Sonidegib did not significantly interfere with the stimulating effect of ionomycin on cell membrane scrambling and did not significantly interfere with the cell shrinkage following hyperosmotic shock, oxidative stress and ionomycin. The insensitivity of cell volume to sonidigib may be due to the lack of effect on cytosolic $\mathrm{Ca}^{2+}$ activity $\left(\left[\mathrm{Ca}^{2+}\right]_{\mathrm{i}}\right)$. A major mechanism accounting for cell shrinkage during eryptosis is increase of $\left[\mathrm{Ca}^{2+}\right]_{i}$ with subsequent activation of $\mathrm{Ca}^{2+}$ sensitive $\mathrm{K}^{+}$channels, $\mathrm{K}^{+}$exit, cell membrane hyperpolarization, $\mathrm{Cl}^{-}$exit and thus cellular loss of $\mathrm{KCl}$ with water. The mechanism accounting for the inhibitory effect of sonidegib on cell membrane scrambling remained, however elusive.

The present study did not elucidate the sonidegib dependent signaling accounting for or contributing to the inhibitory effect of sonidegib on cell membrane scrambling following energy depletion, hyperosmotic shock and oxidative stress. At least in theory, sonidegib could have been effective by inhibition of smoothened and thus by interference with the hedgehog pathway, which plays a decisive role in erythroid differentiation [100, 101]. How hedgehog signaling could interfere with triggering of cell membrane scrambling following energy depletion, hyperosmotic shock and oxidative stress, remains elusive. Clearly, the effect of sonidigib on cell membrane scrambling was not due to an effect on $\left[\mathrm{Ca}^{2+}\right]_{\mathrm{i}}$. Moreover, sonidigib did not interfere with the effect of ionomycin. Possibly, sonidigib is effective by modifying $\mathrm{Ca}^{2+}$ sensitivity of cell membrane scrambling, an effect overridden by ionomycin.

As sonidegib is inhibiting rather than stimulating eryptosis, the enhanced incidence of anemia following treatment with sonidegib cannot be explained by stimulation of eryptosis. As phosphatidylserine exposing erythrocytes are rapidly cleared from circulating blood [12], anemia may result from stimulation but not inhibition of eryptosis. Presumably, the anemia following sonidegib treatment is the result of hemolysis or of impaired erythroid differentiation and erythropoiesis $[100,101]$.

Sonidegib slightly, but significantly, interfered with cell shrinkage following energy depletion. The purpose of erythrocyte shrinkage during eryptosis is the avoidance of hemolysis with release of hemoglobin, which otherwise could pass the renal glomerular filter, precipitate in the acidic lumen of renal tubules, occlude nephrons and thus trigger renal failure [102]. Inhibition of eryptosis may, at least in theory, augment hemolysis and thus enhance renal injury. This may be particularly true for sonidegib, as it stimulates hemolysis.

The inhibitory effect of sonidegib on cell membrane scrambling could be favourable for the vascular system, as phosphatidylserine exposing erythrocytes adhere to the vascular wall [103], stimulate blood clotting/thrombosis [104-106], and interfere with microcirculation $[18,104,107-110]$.

Moreover, inhibition of eryptosis may counteract anemia, a common clinical disorder of malignancy and its treatment [111-119]. Anemia in malignancy is at least in part due to eryptosis, which is triggered by both, the disease and by cytostatic treatment $[13,15,44,47$, $50,53-55,62,65,74,76,88,111,120-128]$. Anemia correlates with unfavourable outcome $[112,113,129-132]$ and drugs are thus needed which counteract tumor growth and by the same token inhibit eryptosis. Despite its inhibitory effect on eryptosis, sonidegib causes, 


\section{Cellular Physiology Cell Physiol Biochem 2018;47:1352-1364 \begin{tabular}{lll} 
DOI: 10.1159/000490820 & and Biochemistry \\
Published online: June 22, 2018 & $\begin{array}{l}\text { O } 2018 \text { The Author(s). Published by S. Karger AG, Basel } \\
\text { www.karger.com/cpb }\end{array}$ \\
\cline { 2 - 3 }
\end{tabular}}

Al Mamun Bhuyan et al.: Sonidegib-Induced Eryptosis

however, anemia $[100,101]$. According to the present observations, the anemiac ould at least in part be due to stimulation of hemolysis.

In conclusion, sonidegib inhibits erythrocyte cell membrane scrambling following energy depletion, hyperosmotic shock and oxidative stress as well as cell shrinkage following energy depeletion and thus counteracts suicidal erythrocyte death.

\section{Acknowledgements}

The authors acknowledge the meticulous preparation of the manuscript by Lejla Subasic. The study was supported by the Deutsche Forschungsgemeinschaft and the open access publishing fund of the University Tübingen.

\section{Disclosure Statement}

The authors declare to have no conflict of interests.

\section{References}

1 Jain S, Song R, Xie J: Sonidegib: mechanism of action, pharmacology, and clinical utility for advanced basal cell carcinomas. Onco Targets Ther 2017;10:1645-1653.

-2 Wahid M, Jawed A, Dar SA, Mandal RK, Haque S: Differential pharmacology and clinical utility of sonidegib in advanced basal cell carcinoma. Onco Targets Ther 2017;10:515-520.

-3 Doan HQ Silapunt S, Migden MR: Sonidegib, a novel smoothened inhibitor for the treatment of advanced basal cell carcinoma. Onco Targets Ther 2016;9:5671-5678.

4 Collier NJ, Ali FR, Lear JT: The safety and efficacy of sonidegib for the treatment of locally advanced basal cell carcinoma. Expert Rev Anticancer Ther 2016;16:1011-1018.

5 Ramelyte E, Amann VC, Dummer R: Sonidegib for the treatment of advanced basal cell carcinoma. Expert Opin Pharmacother 2016;17:1963-1968.

6 Chen L, Silapunt S, Migden MR: Sonidegib for the treatment of advanced basal cell carcinoma: a comprehensive review of sonidegib and the BOLT trial with 12-month update. Future Oncol 2016;12:20952105.

7 Dummer R, Guminski A, Gutzmer R, Dirix L, Lewis KD, Combemale P, Herd RM, Kaatz M, Loquai C, Stratigos AJ, Schulze HJ, Plummer R, Gogov S, Pallaud C, Yi T, Mone M, Chang AL, Cornelis F, Kudchadkar R, Trefzer U, Lear JT, Sellami D, Migden MR: The 12-month analysis from Basal Cell Carcinoma Outcomes with LDE225 Treatment (BOLT): A phase II, randomized, double-blind study of sonidegib in patients with advanced basal cell carcinoma. J Am Acad Dermatol 2016;75:113-125.e115.

-8 Migden MR, Guminski A, Gutzmer R, Dirix L, Lewis KD, Combemale P, Herd RM, Kudchadkar R, Trefzer U, Gogov S, Pallaud C, Yi T, Mone M, Kaatz M, Loquai C, Stratigos AJ, Schulze HJ, Plummer R, Chang AL, Cornelis F, Lear JT, Sellami D, Dummer R: Treatment with two different doses of sonidegib in patients with locally advanced or metastatic basal cell carcinoma (BOLT): a multicentre, randomised, double-blind phase 2 trial. Lancet Oncol 2015;16:716-728.

-9 Burness CB, Scott LJ: Sonidegib: A Review in Locally Advanced Basal Cell Carcinoma. Target Oncol 2016;11:239-246.

10 Wahid M, Jawed A, Mandal RK, Dar SA, Khan S, Akhter N, Haque S: Vismodegib, itraconazole and sonidegib as hedgehog pathway inhibitors and their relative competencies in the treatment of basal cell carcinomas. Crit Rev Oncol Hematol 2016;98:235-241.

11 Burness CB: Sonidegib: First Global Approval. Drugs 2015;75:1559-1566.

12 Lang E, Lang F: Mechanisms and pathophysiological significance of eryptosis, the suicidal erythrocyte death. Semin Cell Dev Biol 2015;39:35-42.

13 Lang E, Bissinger R, Qadri SM, Lang F: Suicidal death of erythrocytes in cancer and its chemotherapy: A potential target in the treatment of tumor-associated anemia. Int J Cancer 2017;141:1522-1528.

14 Lang F, Bissinger R, Abed M, Artunc F: Eryptosis - the Neglected Cause of Anemia in End Stage Renal Disease. Kidney Blood Press Res 2017;42:749-760. 


\section{Cellular Physiology Cell Physiol Biochem 2018;47:1352-1364 \begin{tabular}{l|l} 
and Biochemistry Published online: June 22, 2018 & $\begin{array}{l}\text { (c) } 2018 \text { The Author(s). Published by S. Karger AG, Basel } \\
\text { www.karger.com/cpb }\end{array}$
\end{tabular}}

15 Jemaa M, Fezai M, Bissinger R, Lang F: Methods Employed in Cytofluorometric Assessment of Eryptosis, the Suicidal Erythrocyte Death. Cell Physiol Biochem 2017;43:431-444.

16 Qadri SM, Bissinger R, Solh Z, Oldenborg PA: Eryptosis in health and disease: A paradigm shift towards understanding the (patho)physiological implications of programmed cell death of erythrocytes. Blood Rev 2017;31:349-361.

17 Lang PA, Kaiser S, Myssina S, Wieder T, Lang F, Huber SM: Role of Ca2+-activated K+ channels in human erythrocyte apoptosis. Am J Physiol Cell Physiol 2003;285:C1553-C1560.

18 Abed M, Towhid ST, Mia S, Pakladok T, Alesutan I, Borst O, Gawaz M, Gulbins E, Lang F: Sphingomyelinaseinduced adhesion of eryptotic erythrocytes to endothelial cells. Am J Physiol Cell Physiol 2012;303:C991999.

19 Lau IP, Chen H, Wang J, Ong HC, Leung KC, Ho HP, Kong SK: In vitro effect of CTAB- and PEG-coated gold nanorods on the induction of eryptosis/erythroptosis in human erythrocytes. Nanotoxicology 2012;6:847856.

20 Maellaro E, Leoncini S, Moretti D, Del Bello B, Tanganelli I, De Felice C, Ciccoli L: Erythrocyte caspase-3 activation and oxidative imbalance in erythrocytes and in plasma of type 2 diabetic patients. Acta Diabetol 2013;50:489-495.

21 Bissinger R, Lang E, Ghashghaeinia M, Singh Y, Zelenak C, Fehrenbacher B, Honisch S, Chen H, Fakhri H, Umbach AT, Liu G, Rexhepaj R, Liu G, Schaller M, Mack AF, Lupescu A, Birnbaumer L, Lang F, Qadri SM: Blunted apoptosis of erythrocytes in mice deficient in the heterotrimeric G-protein subunit Galphai2. Sci Rep 2016;6:30925.

-22 Lang E, Zelenak C, Eberhard M, Bissinger R, Rotte A, Ghashghaeinia M, Lupescu A, Lang F, Qadri SM: Impact of cyclin-dependent kinase CDK4 inhibition on eryptosis. Cell Physiol Biochem 2015;37:1178-1186.

23 Lang E, Bissinger R, Fajol A, Salker MS, Singh Y, Zelenak C, Ghashghaeinia M, Gu S, Jilani K, Lupescu A, Reyskens KM, Ackermann TF, Foller M, Schleicher E, Sheffield WP, Arthur JS, Lang F, Qadri SM: Accelerated apoptotic death and in vivo turnover of erythrocytes in mice lacking functional mitogen- and stressactivated kinase MSK1/2. Sci Rep 2015;5:17316.

24 Alzoubi K, Egler J, Abed M, Lang F: Enhanced Eryptosis Following Auranofin Exposure. Cell Physiol Biochem 2015;37:1018-1028.

25 Bissinger R, Bouguerra G, Stockinger K, Abbes S, Lang F: Triggering of Suicidal Erythrocyte Death by Topotecan. Cell Physiol Biochem 2015;37:1607-1618.

-26 Bouguerra G, Aljanadi O, Bissinger R, Abbes S, Lang F: Embelin-Induced Phosphatidylserine Translocation in the Erythrocyte Cell Membrane. Cell Physiol Biochem 2015;37:1629-1640.

27 Briglia M, Fazio A, Faggio C, Laufer S, Alzoubi K, Lang F: Triggering of Suicidal Erythrocyte Death by Ruxolitinib. Cell Physiol Biochem 2015;37:768-778.

28 Briglia M, Fazio A, Signoretto E, Faggio C, Lang F: Edelfosine Induced Suicidal Death of Human Erythrocytes. Cell Physiol Biochem 2015;37:2221-2230.

29 Calabro S, Alzoubi K, Faggio C, Laufer S, Lang F: Triggering of Suicidal Erythrocyte Death Following Boswellic Acid Exposure. Cell Physiol Biochem 2015;37:131-142.

-30 Egler J, Lang F: Licochalcone A Induced Suicidal Death of Human Erythrocytes. Cell Physiol Biochem 2015;37:2060-2070.

-31 Fazio A, Briglia M, Faggio C, Alzoubi K, Lang F: Stimulation of Suicidal Erythrocyte Death by Garcinol. Cell Physiol Biochem 2015;37:805-815.

-32 Lang E, Jilani K, Bissinger R, Rexhepaj R, Zelenak C, Lupescu A, Lang F, Qadri SM: Vitamin D-Rich Diet in Mice Modulates Erythrocyte Survival. Kidney Blood Press Res 2015;40:403-412.

33 Officioso A, Alzoubi K, Manna C, Lang F: Clofazimine Induced Suicidal Death of Human Erythrocytes. Cell Physiol Biochem 2015;37:331-341.

-34 Peter T, Bissinger R, Enkel S, Alzoubi K, Oswald G, Lang F: Programmed erythrocyte death following in vitro Treosulfan treatment. Cell Physiol Biochem 2015;35:1372-1380.

-35 Stockinger K, Bissinger R, Bouguerra G, Abbes S, Lang F: Enhanced Eryptosis Following Exposure to Carnosic Acid. Cell Physiol Biochem 2015;37:1779-1791.

-36 Waibel S, Bissinger R, Bouguerra G, Abbes S, Lang F: Saquinavir Induced Suicidal Death of Human Erythrocytes. Cell Physiol Biochem 2015;37:1973-1982.

37 Zierle J, Bissinger R, Egler J, Lang F: Lapatinib Induced Suicidal Death of Human Erythrocytes. Cell Physiol Biochem 2015;37:2275-2287. 


\section{Cellular Physiology Cell Physiol Biochem 2018;47:1352-1364 \begin{tabular}{l|l} 
DOI: 10.1159/000490820 & $\begin{array}{l}\text { O 2018 The Author(s). Published by S. Karger AG, Basel } \\
\text { www.karger.com/cpb }\end{array}$
\end{tabular}}

Al Mamun Bhuyan et al.: Sonidegib-Induced Eryptosis

38 Bissinger R, Waibel S, Bouguerra G, Al Mamun Bhuyan A, Abbes S, Lang F: Enhanced Eryptosis Following Exposure to Lopinavir. Cell Physiol Biochem 2015;37:2486-2495.

39 Briglia M, Fazio A, Faggio C, Lang F: Triggering of Suicidal Erythrocyte Death by Zosuquidar. Cell Physiol Biochem 2015;37:2355-2365.

40 Fazio A, Briglia M, Faggio C, Alzoubi K, Lang F: Oxaliplatin Induced Suicidal Death of Human Erythrocytes. Cell Physiol Biochem 2015;37:2393-2404.

41 Macczak A, Cyrkler M, Bukowska B, Michalowicz J: Eryptosis-inducing activity of bisphenol A and its analogs in human red blood cells (in vitro study). J Hazard Mater 2016;307:328-335.

$\checkmark 42$ Officioso A, Manna C, Alzoubi K, Lang F: Bromfenvinphos induced suicidal death of human erythrocytes. Pestic Biochem Physiol 2016;126:58-63.

43 Qadri SM, Donkor DA, Bhakta V, Eltringham-Smith LJ, Dwivedi DJ, Moore JC, Pepler L, Ivetic N, Nazi I, Fox-Robichaud AE, Liaw PC, Sheffield WP: Phosphatidylserine externalization and procoagulant activation of erythrocytes induced by Pseudomonas aeruginosa virulence factor pyocyanin. J Cell Mol Med 2016;10.1111/jcmm.12778

44 Zierle J, Bissinger R, Bouguerra G, Abbes S, Lang F: Triggering of Suicidal Erythrocyte Death by Regorafenib. Cell Physiol Biochem 2016;38:160-172.

45 Pagano M, Faggio C: The use of erythrocyte fragility to assess xenobiotic cytotoxicity. Cell Biochem Funct 2015;33:351-355.

-46 Al Mamun Bhuyan A, Signoretto E, Bissinger R, Lang F: Enhanced Eryptosis Following Exposure to Dolutegravir. Cell Physiol Biochem 2016;39:639-650.

47 Al Mamun Bhuyan A, Signoretto E, Lang F: Triggering of Suicidal Erythrocyte Death by Psammaplin A. Cell Physiol Biochem 2016;39:908-918.

-48 Almasry M, Jemaa M, Mischitelli M, Faggio C, Lang F: Stimulation of Suicidal Erythrocyte Death by Phosphatase Inhibitor Calyculin A. Cell Physiol Biochem 2016;40:163-171.

-49 Bissinger R, Bhuyan AA, Signoretto E, Lang F: Stimulating Effect of Elvitegravir on Suicidal Erythrocyte Death. Cell Physiol Biochem 2016;38:1111-1120.

-50 Egler J, Zierle J, Lang F: Stimulating Effect of Manumycin A on Suicidal Erythrocyte Death. Cell Physiol Biochem 2016;38:1147-1156.

51 Mischitelli M, Jemaa M, Almasry M, Faggio C, Lang F: Stimulation of Erythrocyte Cell Membrane Scrambling by Quinine. Cell Physiol Biochem 2016;40:657-667.

52 Mischitelli M, Jemaa M, Almasry M, Faggio C, Lang F: Stimulation of Suicidal Erythrocyte Death by Rottlerin. Cell Physiol Biochem 2016;40:558-566.

53 Mischitelli M, Jemaa M, Almasry M, Faggio C, Lang F: Triggering of Suicidal Erythrocyte Death by Fascaplysin. Cell Physiol Biochem 2016;39:1638-1647.

54 Mischitelli M, Jemaa M, Almasry M, Faggio C, Lang F: Ca2+ Entry, Oxidative Stress, Ceramide and Suicidal Erythrocyte Death Following Diosgenin Treatment. Cell Physiol Biochem 2016;39:1626-1637.

55 Mischitelli M, Jemaa M, Almasry M, Faggio C, Lang F: Triggering of Erythrocyte Cell Membrane Scrambling by Emodin. Cell Physiol Biochem 2016;40:91-103.

-56 Peter T, Bissinger R, Lang F: Stimulation of Eryptosis by Caspofungin. Cell Physiol Biochem 2016;39:939949.

57 Peter T, Bissinger R, Liu G, Lang F: Anidulafungin-Induced Suicidal Erythrocyte Death. Cell Physiol Biochem 2016;38:2272-2284.

58 Peter T, Bissinger R, Signoretto E, Mack AF, Lang F: Micafungin-Induced Suicidal Erythrocyte Death. Cell Physiol Biochem 2016;39:584-595.

59 Pretorius E, du Plooy JN, Bester J: A Comprehensive Review on Eryptosis. Cell Physiol Biochem 2016;39:1977-2000.

60 Shan F, Yang R, Ji T, Jiao F: Vitamin C Inhibits Aggravated Eryptosis by Hydrogen Peroxide in Glucose-6Phosphated Dehydrogenase Deficiency. Cell Physiol Biochem 2016;39:1453-1462.

61 Signoretto E, Honisch S, Briglia M, Faggio C, Castagna M, Lang F: Nocodazole Induced Suicidal Death of Human Erythrocytes. Cell Physiol Biochem 2016;38:379-392.

62 Signoretto E, Laufer SA, Lang F: Stimulating Effect of Sclareol on Suicidal Death of Human Erythrocytes. Cell Physiol Biochem 2016;39:554-564.

63 Signoretto E, Zierle J, Bissinger R, Castagna M, Bossi E, Lang F: Triggering of Suicidal Erythrocyte Death by Pazopanib. Cell Physiol Biochem 2016;38:926-938. 


\section{Cellular Physiology Cell Physiol Biochem 2018;47:1352-1364 \begin{tabular}{l|l} 
and Biochemistry Published online: June 22, 2018 & $\begin{array}{l}\text { (c) } 2018 \text { The Author(s). Published by S. Karger AG, Basel } \\
\text { www.karger.com/cpb }\end{array}$
\end{tabular}}

Al Mamun Bhuyan et al.: Sonidegib-Induced Eryptosis

64 Wesseling MC, Wagner-Britz L, Huppert H, Hanf B, Hertz L, Nguyen DB, Bernhardt I: Phosphatidylserine Exposure in Human Red Blood Cells Depending on Cell Age. Cell Physiol Biochem 2016;38:1376-1390.

-65 Zierle J, Bissinger R, Lang F: Inhibition by Teriflunomide of Erythrocyte Cell Membrane Scrambling Following Energy Depletion, Oxidative Stress and Ionomycin. Cell Physiol Biochem 2016;39:1877-1890.

66 Bissinger R, Modicano P, Alzoubi K, Honisch S, Faggio C, Abed M, Lang F: Effect of saponin on erythrocytes. Int J Hematol 2014;100:51-59.

67 Bissinger R, Modicano P, Frauenfeld L, Lang E, Jacobi J, Faggio C, Lang F: Estramustine-induced suicidal erythrocyte death. Cell Physiol Biochem 2013;32:1426-1436.

-68 Voelkl J, Alzoubi K, Mamar AK, Ahmed MS, Abed M, Lang F: Stimulation of suicidal erythrocyte death by increased extracellular phosphate concentrations. Kidney Blood Press Res 2013;38:42-51.

69 Al Mamun Bhuyan A, Bissinger R, Cao H, Lang F: Triggering of Suicidal Erythrocyte Death by Bexarotene. Cell Physiol Biochem 2016;40:1239-1251.

70 Bissinger R, Barking S, Alzoubi K, Liu G, Liu G, Lang F: Stimulation of Suicidal Erythrocyte Death by the Antimalarial Drug Mefloquine. Cell Physiol Biochem 2015;36:1395-1405.

71 Bissinger R, Bouguerra G, Al Mamun Bhuyan A, Waibel S, Abbes S, Lang F: Efavirenz Induced Suicidal Death of Human Erythrocytes. Cell Physiol Biochem 2015;37:2496-2507.

72 Briglia M, Calabro S, Signoretto E, Alzoubi K, Laufer S, Faggio C, Lang F: Fucoxanthin Induced Suicidal Death of Human Erythrocytes. Cell Physiol Biochem 2015;37:2464-2475.

73 Faggio C, Alzoubi K, Calabro S, Lang F: Stimulation of suicidal erythrocyte death by PRIMA-1. Cell Physiol Biochem 2015;35:529-540.

74 Jemaa M, Mischitelli M, Fezai M, Almasry M, Faggio C, Lang F: Stimulation of Suicidal Erythrocyte Death by the CDC25 Inhibitor NSC-95397. Cell Physiol Biochem 2016;40:597-607.

-75 Lang E, Modicano P, Arnold M, Bissinger R, Faggio C, Abed M, Lang F: Effect of thioridazine on erythrocytes. Toxins (Basel) 2013;5:1918-1931.

76 Signoretto E, Bissinger R, Castagna M, Lang F: Stimulation of Eryptosis by Combretastatin A4 Phosphate Disodium (CA4P). Cell Physiol Biochem 2016;38:969-981.

77 Bouguerra G, Bissinger R, Abbes S, Lang F: Stimulation of Eryptosis by Narasin. Cell Physiol Biochem 2015;37:1807-1816.

-78 Abed M, Feger M, Alzoubi K, Pakladok T, Frauenfeld L, Geiger C, Towhid ST, Lang F: Sensitization of erythrocytes to suicidal erythrocyte death following water deprivation. Kidney Blood Press Res 2013;37:567-578.

79 Abed M, Artunc F, Alzoubi K, Honisch S, Baumann D, Foller M, Lang F: Suicidal erythrocyte death in endstage renal disease. J Mol Med (Berl) 2014;92:871-879.

80 Ahmed MS, Langer H, Abed M, Voelkl J, Lang F: The uremic toxin acrolein promotes suicidal erythrocyte death. Kidney Blood Press Res 2013;37:158-167.

81 Polak-Jonkisz D, Purzyc L: Ca(2+) influx versus efflux during eryptosis in uremic erythrocytes. Blood Purif 2012;34:209-210; author reply 210.

-82 Calderon-Salinas JV, Munoz-Reyes EG, Guerrero-Romero JF, Rodriguez-Moran M, Bracho-Riquelme RL, Carrera-Gracia MA, Quintanar-Escorza MA: Eryptosis and oxidative damage in type 2 diabetic mellitus patients with chronic kidney disease. Mol Cell Biochem 2011;357:171-179.

83 Bissinger R, Artunc F, Qadri SM, Lang F: Reduced Erythrocyte Survival in Uremic Patients Under Hemodialysis or Peritoneal Dialysis. Kidney Blood Press Res 2016;41:966-977.

84 Lang PA, Beringer O, Nicolay JP, Amon O, Kempe DS, Hermle T, Attanasio P, Akel A, Schafer R, Friedrich B, Risler T, Baur M, Olbricht CJ, Zimmerhackl LB, Zipfel PF, Wieder T, Lang F: Suicidal death of erythrocytes in recurrent hemolytic uremic syndrome. J Mol Med (Berl) 2006;84:378-388.

-85 Nicolay JP, Schneider J, Niemoeller OM, Artunc F, Portero-Otin M, Haik G, Jr., Thornalley PJ, Schleicher E, Wieder T, Lang F: Stimulation of suicidal erythrocyte death by methylglyoxal. Cell Physiol Biochem 2006;18:223-232.

-86 Lang E, Pozdeev VI, Gatidis S, Qadri SM, Haussinger D, Kubitz R, Herebian D, Mayatepek E, Lang F, Lang KS, Lang PA: Bile Acid-Induced Suicidal Erythrocyte Death. Cell Physiol Biochem 2016;38:1500-1509.

-87 Lang E, Gatidis S, Freise NF, Bock H, Kubitz R, Lauermann C, Orth HM, Klindt C, Schuier M, Keitel V, Reich M, Liu G, Schmidt S, Xu HC, Qadri SM, Herebian D, Pandyra AA, Mayatepek E, Gulbins E, Lang F, Haussinger D, Lang KS, Foller M, Lang PA: Conjugated bilirubin triggers anemia by inducing erythrocyte death. Hepatology 2015;61:275-284. 


\section{Cellular Physiology Cell Physiol Biochem 2018;47:1352-1364

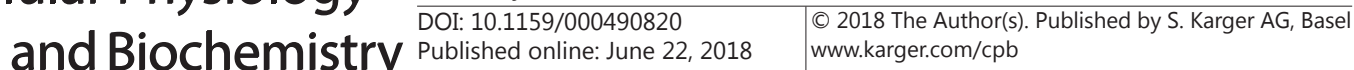 \\ Published online: June 22,2018 in}

88 Bissinger R, Schumacher C, Qadri SM, Honisch S, Malik A, Gotz F, Kopp HG, Lang F: Enhanced eryptosis contributes to anemia in lung cancer patients. Oncotarget 2016;7:14002-14014.

89 Qadri SM, Mahmud H, Lang E, Gu S, Bobbala D, Zelenak C, Jilani K, Siegfried A, Foller M, Lang F: Enhanced suicidal erythrocyte death in mice carrying a loss-of-function mutation of the adenomatous polyposis coli gene. J Cell Mol Med 2012;16:1085-1093.

90 Bartolmas T, Mayer B, Balola AH, Salama A: Eryptosis in autoimmune haemolytic anaemia. Eur J Haematol 2018;100:36-44.

-91 Qadri SM, Donkor DA, Nazy I, Branch DR, Sheffield WP: Bacterial neuraminidase-mediated erythrocyte desialylation provokes cell surface aminophospholipid exposure. Eur J Haematol 2018;100:502-510.

$\$ 92$ Bissinger R, Kempe-Teufel DS, Honisch S, Qadri SM, Randrianarisoa E, Haring HU, Henes J, Lang F: Stimulated Suicidal Erythrocyte Death in Arteritis. Cell Physiol Biochem 2016;39:1068-1077.

-93 Kempe DS, Akel A, Lang PA, Hermle T, Biswas R, Muresanu J, Friedrich B, Dreischer P, Wolz C, Schumacher U, Peschel A, Gotz F, Doring G, Wieder T, Gulbins E, Lang F: Suicidal erythrocyte death in sepsis. J Mol Med (Berl) 2007;85:273-281.

-94 Lang PA, Schenck M, Nicolay JP, Becker JU, Kempe DS, Lupescu A, Koka S, Eisele K, Klarl BA, Rubben H, Schmid KW, Mann K, Hildenbrand S, Hefter H, Huber SM, Wieder T, Erhardt A, Haussinger D, Gulbins E, Lang F: Liver cell death and anemia in Wilson disease involve acid sphingomyelinase and ceramide. Nat Med 2007;13:164-170.

$\$ 95$ Lupescu A, Bissinger R, Goebel T, Salker MS, Alzoubi K, Liu G, Chirigiu L, Mack AF, Qadri SM, Lang F: Enhanced suicidal erythrocyte death contributing to anemia in the elderly. Cell Physiol Biochem 2015;36:773-783.

-96 Lang E, Pozdeev VI, Xu HC, Shinde PV, Behnke K, Hamdam JM, Lehnert E, Scharf RE, Lang F, Haussinger D, Lang KS, Lang PA: Storage of Erythrocytes Induces Suicidal Erythrocyte Death. Cell Physiol Biochem 2016;39:668-676.

-97 Qadri SM, Chen D, Schubert P, Devine DV, Sheffield WP: Early gamma-irradiation and subsequent storage of red cells in SAG-M additive solution potentiate energy imbalance, microvesiculation and susceptibility to stress-induced apoptotic cell death. Vox Sang 2017;112:480-483.

-98 Qadri SM, Chen D, Schubert P, Perruzza DL, Bhakta V, Devine DV, Sheffield WP: Pathogen inactivation by riboflavin and ultraviolet light illumination accelerates the red blood cell storage lesion and promotes eryptosis. Transfusion 2017;57:661-673.

-99 Goel V, Hurh E, Stein A, Nedelman J, Zhou J, Chiparus O, Huang PH, Gogov S, Sellami D: Population pharmacokinetics of sonidegib (LDE225), an oral inhibitor of hedgehog pathway signaling, in healthy subjects and in patients with advanced solid tumors. Cancer Chemother Pharmacol 2016;77:745-755.

100 Roy A, Haldar S, Basak NP, Banerjee S: Molecular cross talk between Notch1, Shh and Akt pathways during erythroid differentiation of K562 and HEL cell lines. Exp Cell Res 2014;320:69-78.

101 Detmer K, Walker AN, Jenkins TM, Steele TA, Dannawi H: Erythroid differentiation in vitro is blocked by cyclopamine, an inhibitor of hedgehog signaling. Blood Cells Mol Dis 2000;26:360-372.

102 Harrison HE, Bunting H, Ordway NK, Albrink WS: The Pathogenesis of the Renal Injury Produced in the Dog by Hemoglobin or Methemoglobin. J Exp Med 1947;86:339-356.

-103 Borst O, Abed M, Alesutan I, Towhid ST, Qadri SM, Foller M, Gawaz M, Lang F: Dynamic adhesion of eryptotic erythrocytes to endothelial cells via CXCL16/SR-PSOX. Am J Physiol Cell Physiol 2012;302:C644-C651.

104 Andrews DA, Low PS: Role of red blood cells in thrombosis. Curr Opin Hematol 1999;6:76-82.

105 Chung SM, Bae ON, Lim KM, Noh JY, Lee MY, Jung YS, Chung JH: Lysophosphatidic acid induces thrombogenic activity through phosphatidylserine exposure and procoagulant microvesicle generation in human erythrocytes. Arterioscler Thromb Vasc Biol 2007;27:414-421.

106 Zwaal RF, Comfurius P, Bevers EM: Surface exposure of phosphatidylserine in pathological cells. Cell Mol Life Sci 2005;62:971-988.

107 Closse C, Dachary-Prigent J, Boisseau MR: Phosphatidylserine-related adhesion of human erythrocytes to vascular endothelium. Br J Haematol 1999;107:300-302.

108 Gallagher PG, Chang SH, Rettig MP, Neely JE, Hillery CA, Smith BD, Low PS: Altered erythrocyte endothelial adherence and membrane phospholipid asymmetry in hereditary hydrocytosis. Blood 2003;101:46254627.

109 Pandolfi A, Di Pietro N, Sirolli V, Giardinelli A, Di Silvestre S, Amoroso L, Di Tomo P, Capani F, Consoli A, 


\section{Cellular Physiology Cell Physiol Biochem 2018;47:1352-1364

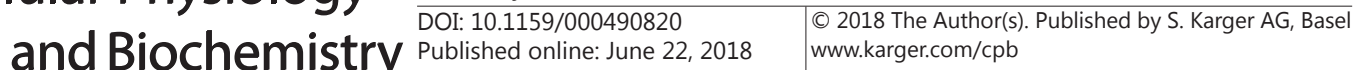

Al Mamun Bhuyan et al.: Sonidegib-Induced Eryptosis

Bonomini M: Mechanisms of uremic erythrocyte-induced adhesion of human monocytes to cultured endothelial cells. J Cell Physiol 2007;213:699-709.

110 Wood BL, Gibson DF, Tait JF: Increased erythrocyte phosphatidylserine exposure in sickle cell disease: flowcytometric measurement and clinical associations. Blood 1996;88:1873-1880.

111 Ibrahim UA, Yusuf AA, Ahmed SG: The Pathophysiologic Basis of Anaemia in Patients with Malignant Diseases. Gulf J Oncolog 2016;1:80-89.

112 Mhaskar R, Wao H, Miladinovic B, Kumar A, Djulbegovic B: The role of iron in the management of chemotherapy-induced anemia in cancer patients receiving erythropoiesis-stimulating agents. Cochrane Database Syst Rev 2016;2:CD009624.

113 Testa U, Castelli G, Elvira P: Experimental and investigational therapies for chemotherapy-induced anemia. Expert Opin Investig Drugs 2015;24:1433-1445.

114 Shah N, Andrews J, Goodnough LT: Transfusions for anemia in adult and pediatric patients with malignancies. Blood Rev 2015;29:291-299.

115 Lamy PJ, Durigova A, Jacot W: Iron homeostasis and anemia markers in early breast cancer. Clin Chim Acta 2014;434:34-40.

116 Gaspar BL, Sharma P, Das R: Anemia in malignancies: pathogenetic and diagnostic considerations. Hematology 2015;20:18-25.

117 Gilreath JA, Stenehjem DD, Rodgers GM: Diagnosis and treatment of cancer-related anemia. Am J Hematol 2014;89:203-212.

118 Gao S, Ma JJ, Lu C: Venous thromboembolism risk and erythropoiesis-stimulating agents for the treatment of cancer-associated anemia: a meta-analysis. Tumour Biol 2014;35:603-613.

$>119$ Adamson JW: Iron, erythropoietic stimulating agents, and anemia in cancer. Crit Rev Oncog 2013;18:471483.

120 Al Mamun Bhuyan A, Ashiqul Haque AKM, Sahu I, Cao H, Kormann MSD, Lang F: Inhibition of Suicidal Erythrocyte Death by Volasertib. Cell Physiol Biochem 2017;43:1472-1486.

121 Al Mamun Bhuyan A, Nussle S, Cao H, Zhang S, Lang F: Simvastatin, a Novel Stimulator of Eryptosis, the Suicidal Erythrocyte Death. Cell Physiol Biochem 2017;43:492-506.

122 Al Mamun Bhuyan A, Cao H, Lang F: Triggering of Eryptosis, the Suicidal Erythrocyte Death by Mammalian Target of Rapamycin (mTOR) inhibitor Temsirolimus. Cell Physiol Biochem 2017;42:1575-1591.

123 Egler J, Lang F: Triggering of Eryptosis, the Suicidal Erythrocyte Death, by Perifosine. Cell Physiol Biochem 2017;41:2534-2544.

124 Almasry M, Jemaa M, Mischitelli M, Lang F, Faggio C: Camalexin-Induced Cell Membrane Scrambling and Cell Shrinkage in Human Erythrocytes. Cell Physiol Biochem 2017;41:731-741.

125 Abed M, Alzoubi K, Lang F, Al Mamun Bhuayn A: Stimulation of Phospholipid Scrambling of the Erythrocyte Membrane by 9-Cis-Retinoic Acid. Cell Physiol Biochem 2017;41:543-554.

126 Mischitelli M, Jemaaa M, Fezai M, Almasry M, Lang F, Faggio C: Stimulation of Erythrocyte Cell Membrane Scrambling by Adarotene. Cell Physiol Biochem 2017;41:519-529.

127 Waibel S, Bissinger R, Bouguerra G, Abbes S, Lang F: Ritonavir-Induced Suicidal Death of Human Erythrocytes. Basic Clin Pharmacol Toxicol 2016;119:51-57.

128 Signoretto E, Castagna M, Lang F: Stimulation of Eryptosis, the Suicidal Erythrocyte Death by Piceatannol. Cell Physiol Biochem 2016;38:2300-2310.

129 Kelada 0, Marignol L: Erythropoietin-stimulating agents and clinical outcomes in metastatic breast cancer patients with chemotherapy-induced anemia: a closed debate? Tumour Biol 2014;35:5095-5100.

130 Nishikawa K, Takahashi T, Takaishi H, Miki A, Noshiro H, Yoshikawa T, Nishida Y, Iwasa S, Miwa H, Masuishi T, Boku N, Yamada Y, Kodera Y, Yoshida K, Morita S, Sakamoto J, Saji S, Kitagawa Y: Phase II study of the effectiveness and safety of trastuzumab and paclitaxel for taxane- and trastuzumab-naive patients with HER2-positive, previously treated, advanced, or recurrent gastric cancer (JFMC45-1102). Int J Cancer 2017;140:188-196.

131 Cui R, Chu L, Liu ZQ, Xiao YY, Zhu XL, Chen YJ, Xu Q: Hematologic toxicity assessment in solid tumor patients treated with cetuximab: A pooled analysis of 18 randomized controlled trials. Int J Cancer 2016;138:27712773.

132 Zhang J, Wang Z, Hu X, Wang B, Wang L, Yang W, Liu Y, Liu G, Di G, Hu Z, Wu J, Shao Z: Cisplatin and gemcitabine as the first line therapy in metastatic triple negative breast cancer. Int J Cancer 2015;136:204211. 